\title{
ROLE OF NIGELLA SATIVA IN DECREASING MORTALITIES IN NILE TILAPIA CAUSED BY PSEUDOMONAS SEPTICEMIA
}

\author{
AYA GALAL SAAD EL-DEEN \\ Animal Health Research Institute, Assiut Laboratory \\ E-Mail: aya9galal@gmail.com
}

\section{ABSTRACT}

Received at: $17 / 5 / 2014$

Accepted: 17/7/2014
This work was carried out to investigate Pseudomonal septicemia in Nile tilapia, Oreochromis niloticus, at Assiut governorate and to evaluate the effects of oral administration of black cumin Nigella sativa on resistance against Pseudomonas aeraginosa infection. A total of 100 Nile tilapia were collected from River Nile and El-Ibrahemia canal, Assiut governorate, and were subjected to clinical and bacteriological examination. Pseudomonase like isolates were detected from 29 out of 100 collected and examined fish samples (The incidence of pseudomonase infection was 29\%). Biochemically, the collected isolates were identified as $P$. aureginosa and $P$. putida and other unidentified pseudomonase species. The organisms were mainly isolated from liver, spleen and kidney. The pathogenicity of the isolated $P$. aureginosa from Nile tilapia was confirmed by an experimental pathogenicity challenge. A total of 90 Nile tilapia were divided into two equal groups with three replicates to investigate the effect of dietary supplementation of black cumin on diseased resistance throughout the experimental challenge. Fish of the first group were fed on basic diet, while fish of the second group fed on basic diet with $3 \%$ black cumin $/ \mathrm{kg}$ diet ( $3 \mathrm{~g}$. black cumin $/ 100 \mathrm{~g}$ diet) for 30 successive days. Experimental challenge was done by immersion where the infected fish showed typical signs of pseudomonal septicemia; redness all over the body, ulceration, scales detachment, darkening of body and congestion of all internal organs. Cumulative mortalities of fish challenged were significantly less in groups fed on black cumin diet $(13.33 \%)$ than those fed on the basic diets $(53.33 \%)$. Moreover, lesions and symptoms were less or sporadically seen in group treated with black cumin. These results showed black cumin improve the fish resistance to disease.

Key words: Pseudomonal septicemia, Nile tilapia, black cumin

\section{INTRODUCTION}

Bacterial pathogens are the causative agents of most serious disease problems in both wild and cultured fish causing mortalities and severe economic losses (Roberts, 2001). Pseudomonas infection has been incriminated as an important bacterial infection among fish and appear to be stress related disease of freshwater fish especially under culture conditions (Kitao et al., 1993)

Pseudomonades are opportunistic Gram negative pathogens, naturally occur in aquatic environment and as a part of normal gut flora of healthy fish, it causes outbreak when the optimum environmental conditions change (Angelini and Seigneur 1988). The genus Pseudomonas contains five species which have been described as etiological agents of diseases in fish in Egypt. Pseudomonas fluorescens, P. angulliseptica, $P$. aeruginosa and $P$. putida were identified in various species of fish as causative agents of pseudomonas septicemia (Sakar and Azza 2008 and EL-Nagar 2010), which characterized by fin rot, petechial hemorrhage, darkness of the skin, detached scales, abdominal ascitis and exophthalmia (Khalil et al., 2010).

Using natural feed additive is becoming useful for fish feeding rather than classic chemical feed additives due to the cumulative effects of the chemical components induced deterrent effects on human health (El-Dakar et al., 2008). Black cumin, Nigella sativa, an annual herb that belongs to the botanical family of Ranuculaceae, showed antibacterial, fungicidal effects (Akgul, 1989). Black cumin have been used as enhancer for performance, growth and immune system of some fish species (Abdel-Ghaffar et al., 2003; Diab et al., 2008)

The aim of the present study was to investigate the incidence of pseudomonas species in Nile tilapia at Assiut governorate, as well as the pathogencity of the 
isolated bacteria to Nile tilapia. This study was also performed to evaluate the effect of dietary supplementation of black cumin on diseases resistance of Nile tilapia challenged with pseudomonas.

\section{MATERIALS and METHODS}

\section{Clinical and Postmortem Examination of Naturally Infected Fish: \\ A total of 100 alive Nile tilapia, Oreochromis niloticus, and weighing 100-350 g with total length of 14-26 cm were collected from El-Ibrahemia canal and River Nile from November 2012 to April 2013. Fish were transported immediately to the Aquatic Animals Wet Lab., Veterinary Hospital Clinic, Faculty of Veterinary Medicine, Assiut University. Fish were subjected to clinical and bacteriological examination (Plumb and Bowser, 1982), observed signs were recorded and detected lesions were reported.}

\section{Isolation and Identification of Pseudomonas spp. From Fish:}

Samples from internal organs of the examined fish were streaked onto bile salt brilliant green agar (Lab M), Pseudomonas p. agar medium plates ((Lab M) and brain heart infusion agar ( $\mathrm{Lab} \mathrm{M})$, then incubated at $28^{\circ} \mathrm{C}$ for $24 \mathrm{hr}$. Bacterial colonies were identified according to colony morphology, bacterial staining character, and biochemical character (Palleroni,1984 and Buller, 2008).

\section{Experimental Fish:}

Apparently healthy Nile tilapia with an average body weight of $100 \pm 5 \mathrm{~g}$ were obtained from a private fish farm in waladya area at Assiut Governorate and transported to the Aquatic Animals Wet Lab., Veterinary Clinical Hospital, Faculty of Veterinary Medicine, Assiut University where they kept in well prepared aquaria. Random samples were used to check whether they are Pseudomonal septicemia free. Fish were acclimated for 2 weeks according to the protocol of maintaining bioassay fish as was previously described by Ellsaesser and Clem (1986) and received commercial food.

\section{Experimental challenge: \\ Bacterial strain:}

Bacterial strains were kept in BHI broth with $15 \%$ glycerol (El-Gomhurrhia, Cairo, Egypt) at $-20^{\circ} \mathrm{C}$. Pseudomonas aeraginosa strain was passed three times in Nile tilapia through intraperitoneal injection before using for experimental challenge.

Bacterial challenge suspension and counts:

Colony forming units (cfu) counts in bacterial suspensions were determined using spectrophometery optical density values at wavelength of $600 \mathrm{~nm}$ and standard-plate-count method with ten-fold serial dilution (Elkamel and Thune, 2003).

\section{Experimental challenge:}

Acclimated Nile tilapia were divided into three groups with 15 fish each. The first group was infected through immersion in $1 \times 10^{7} \mathrm{cfu} / \mathrm{ml}$, suspension of p. aeraginosa for 30 minutes in $30 \mathrm{~L}$, while the second group was subjected to sterile BHI broth for the same duration and the other group remained unchallenged. The whole experiment was repeated three times. Reisolation and identification of the inoculated organism from freshly dead and moribund fish were carried out as described above.

\section{Diets and feed additives:}

Two different diets with or without additives, representing two diet variants, were formulated to be used for feeding of fish. A basic diet (control) was formulated of grounded yellow corn $(34.9 \%)$, soya bean meal $(28.6 \%)$, fish meal $(17.0 \%)$, wheat bran $(9.3 \%)$, vegetable oils $(6.5 \%)$, ground lime stone $(0.70 \%)$, bone meal $(0.30 \%)$, mineral mixture $(1.7 \%)$ and vitamin mixture $(1.0 \%)$. The other experimental diet was formulated as a Nigella diet (3 g. black cumin, $N$. sativa $/ 100$ g. of basic diets).

\section{Experimental design:}

Acclimated Nile tilapia were allotted into two replicates, one replicate received the nigella diet, while the other replicate received the basic diet. Each replicates were subdivided in to three groups (15 fish each). Each replicate was fed twice daily for 30 successive days.

The two challenge groups of each replicates were challenged through immersion in $1 \times 10^{7} \mathrm{cfu} / \mathrm{ml}$ of Pseudomonas aeraginosa for $30 \mathrm{~min}$ in a volume of 30 L. While challenged control groups of each replicates was subjected to sterile BHI broth for the same duration $(30 \mathrm{~min})$, while the other group remained unchallenged. Mortalities and clinical signs were recorded daily for 21 days. Re-isolation and identification of bacteria was done from freshly dead fish as mentioned above. The whole experiment was repeated three times.

\section{RESULTS}

\section{Clinical and postmortem examination:}

Clinical examination of naturally infected fish revealed the presence of septicemia signs on some fish represented by skin darkness and scales detachment in 6 examined fish. Fish exhibited congestion and petechiae on the body surface, especially on the ventral part of abdomen and fins in 22 fish. The postmortem examination revealed congestion of the spleen, kidney and liver in 18 fish. In 17cases, showed enlarged gall bladder and distended with bile. The remaining fish appeared to be clinically healthy.

\section{Bacterial isolation and identification:}

Bacteriological examination resulted in isolation of 34 isolates suspected to be Pseudomonas aureginosa 
$(\mathrm{n}=18)$, Pseudomonas putida $(\mathrm{n}=6)$ and unidentified Pseudomonas spp.(10) according to Morphobiochemical test. Bacterial colonies grown on BHI agar were circulated, convex, entire edge, glistening, creamy color and 1-2 $\mathrm{mm}$ in diameter. On pseudomonas $\mathrm{p}$ agar colonies were greenish white colonies, while on bile salt brilliant green agar, bacterial colonies were whitish, convex and 1-2 mm in diameter. Results of the biochemical characters and enzyme activities of suspected isolates are shown in Table (1).

Results also revealed that the organism could be mainly isolated from spleen, liver, kidney. Pseudomonas existence ratios in different fish organs was 12 in spleen, 10 from liver and 12 from kidney.

Experimental challenge was done by immersion in 1 X $10^{7} \mathrm{CFU} / \mathrm{ml}$ viable cells of $P$. aerugenosa in two groups of fish. The infected fish in two groups of fish display the same clinical signs and postmortem lesions but in different percentage (level). The challenged fish exhibited signs of ulceration on the body and fin rot (in four fish in group 1 and 2 fish in group two). Petechial haemorhage on different part of the body surface especially on the ventral part of abdomen, fin and gill cover were recorded in six fish in group one, however 4 in group two.Dark pigmentation were observed in three fish in group one. Internally there were congestion of all internal organs in eight fish in group one and in two fish in group two. Gall bladder was enlarged and distended by bile. Intestine was filled with bloody serous fluid in two fish of group one (Fig 1).

Mortality rate after bacterial infection showed a significant decrease in Nigella sativa treatment $(\mathrm{p}<0.05)$ in a way that mortality rate in Nigella sativa treatment group, basic diets group and in control group were $13.33 \%, 53.33 \%$ and $0 \%$ respectively.

Table 1: Cultural and biochemical characters of the isolated bacteria $(n=34)$.

\begin{tabular}{lccc}
\hline characters & P.aeraginosa & P.putida & Un-identify strains \\
\hline No. of isolates & 18 & 6 & G-ve \\
\hline Gram stains & G-ve & + & G-ve \\
\hline Motility & + & + & + \\
\hline Oxidase test & + & - & - \\
\hline Indole & - & $-/-$ & $-/-$ \\
\hline O/F test & $-/-$ & + & + \\
\hline Catalase & + & - & $4 / 10$ \\
\hline H2S production & - & - & $2 / 10$ \\
\hline Urease & + & - & - \\
\hline V.P. & - & - & $5 / 10$ \\
\hline M.R. & - & - & $4 / 10$ \\
\hline Gelatin liquification & + & + & $7 / 10$ \\
\hline Growth on 5\%Nacl & + & - & \\
\hline mannitol & + acid only & - & \\
\hline Sucrose & - & - & \\
\hline Lactose & - & - & \\
\hline Maltose & - & & \\
\hline
\end{tabular}

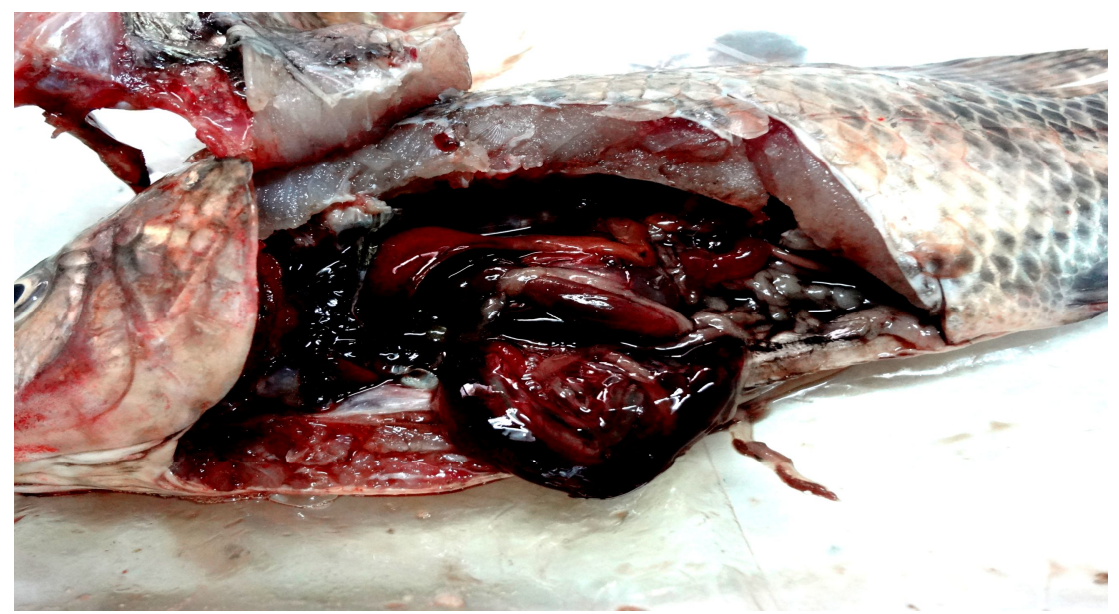

Fig. 1: Nile tilapia, experimentaly infected with Pseudomonase aeraginosa showing congested liver, kidney and bloody fluids filling the intestine 


\section{DISCUSSION}

Pseudomonas septicemia is one of the important pathogenic bacteria affecting fish farm in Egypt (Khalil et al., 2010). The present study was done to assess and characterize the pseudomonas infection in Nile tilapia, O. niloticus in Assiut governorate and to investigate the effect of dietary supplementation of black cumin, Nigella sativa on the diseases resistance of cultured Nile tilapia.

Results revealed that fish naturally infected with Pseudomonas spp. showed signs of infection were nearly similar to those reported by (Khalil et al., 2010, EL-hady and Samy 2011).

Bacteriological analysis of naturally infected fish resulted in the isolation of two different Pseudomonas spp. including P.aeraginosa and P.putida. The isolates showed phenotypic and biochemical characteristics of the isolated $P$. aureginosa and P.putida were parallel to previous studies which identified the same organisms from other fish species (Austin and Austin, 2007 and Buller 2008).

In this study, the incidence of Pseudomonas spp. in the examined $O$. niloticus was $29 \%$. The result supports previous studies of the examined $O$. niloticus 25.5\% (Saleh et al., 2008) and 30.83\% (Eissa et al., 2010). These results are not in agreement with those reported by EL-hady and Samy (2011) who isolated Pseudomonase spp. From $O$. niloticus with percentage of $55.3 \%$.

Regarding the samples of bacterial isolates among various organs of fish, it was revealed that the isolation from liver, spleen and Kidney approximately had the same rates. This result agreed with (ElRefaey, 2013). This may be due to most of bacterial infections affect haemobiotic system mainly liver, kidney and spleen.

Experimental infection was successfully done by immersion. The result of the current study demonstrated that clinical picture of pseudomonas septicemia characterized by signs of dark pigmentation, petechial hemorrhage on different parts of the body surface, ulceration, especially at dorsum part and at the base of fins with eroded fin (fin and tail rot). It may be due to the toxic proteases produced by this organism, thus serving to destroy the body tissues. Hemorrhages at the base of fins could be primarily induced by release of powerful bacterial proteolytic enzymes which lead to electrolyte and protein loss together with disturbed blood circulation (Amlacker, 1970 and Mortia, 1975). Congested internal organs are a septicemic lesion, where the congestion and edema was seen to play a role in the enlargement of kidney, spleen and liver. The over distended gall bladder could be attributed to the enteritis or to encountered constriction of the common bile duct by peri-duct fibrosis, these results are conceited with those noticed by Eissa et al. (2010); Kalil et al. (2010).

The pathogenicity of Pseudomonas spp. For experimentally infected Nile tilapia may be attributed to the production of extracellular enzymes and total toxins (as protease, haemolysins, enterotoxins, enterotoxins cytotoxins and others) (El-Attar and Mostaf 1996) Abou El-Geit et al., 2013).

The challenge infection revealed cumulative mortalities of Nile tilapia were significantly less in fish fed on nigella diets $(13.33 \%)$ than those of fish fed on the basic diets (53.33\%). Moreover, lesions and symptoms were minimized or sporadically seen in group treated with black cumin. In this study, stimulation of the immune system of Nile tilapia as a result of feeding of black cumin diets have positively impacted the resistance of fish to $P$. aeraginosa infection as was indicated by the significantly lower mortality rates of fish challenged with virulent $P$. aeraginosa. It was reported that Ocimum sanctum enhanced the disease resistance in Oreochromis mossambicus against $A$. hydrophila infections (Logambal and Michael 2000). Furthermore, Nile tilapia fed with probiotics and challenged with $A$. hydrophila showed significant decrease in mortalities (Ali et al., 2010). Moreover Y1lma et al. (2012) reported that cumulative mortality was $60 \%$ in fish fed the $0 \%$ control diet and challenged with Streptococcus iniae. However, in fish fed the $2.0 \%$ supplemented diets with black cumin, mortality was only $37.50 \%$. These results are in fair agreement with the administration of herbal supplemented diets showing resistance against streptococcal disease in tilapia fed Rosmarinus officinalis (Abutbul et al., 2004; Zilberg et al., 2010).

This result agreed and explained by (Elkamel and Mosaad 2012) who reported that dietary supplementation of black cumin enhanced the overall immune response of Nile tilapia as was indicated by the significant increase of the WBC numbers, (White blood cells (WBCs) of fish play a crucial role in the cellular immunity and resistance to infectious diseases (Whyte, 2007), globulin proteins and the phagocytic activities of fish phagocytes. This modulation of the fish immunity has greatly enhanced the resistance of challenged fish to $A$. hydrophila as was indicated by the significant decrease in mortalities in fish received the nigella diets. AlDubakel et al. (2012) reported that black cumin enhance $\mathrm{T}$ cell immunity and production of cytokines (Haq et al. 1995), natural killer cell and compliment (Mahdi, 1993). It also inhibit some microbe and has anti-helmintic activity against nematodes and cestodes (Agarwal et al. 1997). Black cumin extract has positive effect on leukocytes (Mona et al., 2002). Diab et al. (2008) argued that black cumin could increase the survival rate and the resistance of fish to some infectious diseases. Black cumin seed could be recommended to be used for farmed fish to decrease 
mortalities caused by pathogenic microorganisms (Dorucu1 et al., 2009).

On conclusion, $P$. aerugenosa can be considered as accountable fish infection under culture condition. The use of $3 \%$ black seeds for 30 days could increase the survival rate and the resistance of fish to some infectious diseases.

\section{REFERENCES}

Abdel-Ghaffar, FA.; El-Feki, MA.; Faheem, HI. and Gad, MA. (2003): Potentiating effects of some natural products on the common carp immune system against Aeromonas hydrophila. J. Aquat Biol Fish 7: 23-47.

Abou El-Geit, E.N.; Saad, T.T.; Abdo, M.H. and Mona S. Zaki. (2013): Microbial infections among some fishes and crustacean species during blooming phenomenon in Qaroun LakeEgypt. Life Science Journal 2013; 10(2).

Abutbul, S.; Golan-Goldhirsh, A.; Barazani, O. and Zilberg, D. (2004): Use of Rosmarinus officinalis as a treatment against Streptococcus iniae in tilapia (Oreochromis sp.). Aquaculture, 238: 97-105.

Agarwal, R.; Kharya, M. and Shrivastva, R. (1997): Antimicrobial and antihelmenthic activities of the essential oil of Nigella sativa. Indian J. Exp. Biol., 17: 1264-1265.

Al-Dubakel, A.Y.; Al-Mhawe, B.H.; Majeed, M.F. and Shaeyal, L.W. (2012): Preliminary study on the effect of dietary black seed (Nigella sativa) on growth and blood glucose of common carp (Cyprinus carpio) fingerlings. J. of Thi _Qar Univ. for Agri. Researches. 1 (2): 41-51.

Ali, HM.; Ghazalah, AA.; Gehad, EA.; Hammouda, $Y A$. and Abo-State, HA. (2010): Practical Aspects and Immune response of Probiotics Preparations Supplemented to Nile Tilapia (Oreochromis Niloticus) Diets. Nature and Science 8: 39-45.

Akgul, A. (1989): Antimicrobial activity of black cumin (Nigella sativa L) essential oil. Gazi Journal of Faculty of Pharmacology 6: 63-68.

Amlacher, E. (1970): Textbook of Fish Diseases trans. D.A. Conroy and R.L. Herman New Jersey: T. F. H. publications.

Angelini, N.M. and Seigneur, G.N. (1988): Disease of the fins of Rhamdia sapo. Isolation of the etiological agents and experimental infection. Rev. Argent. Microbiol., 20: 37-48.

Austin, B. and Austin, D.A. (2007): Bacterial Fish Pathogens, Diseases of Farmed and Wild Fish Fourth Edition, Praxis Publishing Ltd, Chichester UK.

Buller, N.B. (2008): Bacteria from fish and other aquatic animals. A practical identification manual. CABI publishing, Cambridge.

Diab, AS.; Aly, SM.; John, G.; Abde-Hadi, Y. and Mohammed, MF. (2008): Effect of garlic, black seed and Biogen as immunostimulants on the growth and survival of Nile tilapia, Oreochromis niloticus (Teleostei: Cichlidae) and their response to artificial infection with Pseudomonas fluorescens. Afr J Aqu Sci 33: 63-68.

Dorucul, M.; Ozesen Colak, S.; Ispirl, U.; Altinterim1, B. and Celayir, Y. (2009): The Effect of Black Cumin Seeds, Nigella sativa, on the Immune Response of Rainbow Trout, Oncorhynchus mykiss. Mediterranean Aquaculture Journal. 2(1); 27-33.

Eissa, N.M.E.; Abou El-Gheit, E.N.; Shaheen A.A. and Abbass, A. (2010): Caracterization of pseudomonas species isolated from Tilapia “ $O$. niloticus" in Qarun and Wadi-El-Rayan Lakes,Egypt. Glob. Vet., 5, 116 - 121.

El-Attar, A.A. and Moustafa, M. (1996): "Some studies on tail and fin rot disease among cultured Tilapia Fishes". M.Sc. Thesis (Infections diseases) faculty of Vet. Me. Cairo University .

El-Dakar, A.Y.; Hassanien, G.D.; Gad, S.S. and Sakr, S.E. (2008): Use of Dried Basil Leaves as a Feeding Attractant for Hybrid Tilapia, Oreochromis niloticus X Oreochromis aureus, Fingerlings. Mediterranean Aquaculture Journal, 1(1); 35- 44.

EL-Hady, M.A. and Samy, A.A. (2011): Molecular Typing of Pseudomonas Species Isolated from Some Cultured Fishes in Egypt. Global Veterinaria 7 (6): 576-580.

Elkamel, A.A. and Thune, R.L. (2003): Invasion and replication of Photobacterium damselae sub species piscicida in fish cell lines. J. Aquatic Animal Health, 15: 167-174.

Elkamel, A.A. and Mossad, G.M. (2012): Immunomodulation of Nile Tilapia, Oreochromis niloticus, by Nigella sativa and Bacillus subtilis. Aquaculture research and development. 3-6.

Ellsaesser, C.F. and Clem, L.W. (1986): Hematological and immunological changes in channel catfish by handing and transport. Journal of fish biology. 28: 511-521.

El-Nagar, R.M.A. (2010): Bacteriological studies on pseudomonas microorganisms in cultured. M.V.Sc. thesis, Fac. Vet. Med., Zag. University.

El-Refaey, M.E. (2013): Studies on major bacterial diseases affecting fish; Tilapia Oreochromis niloticus, Catfish, Clarias gariepinus and mullets in Port Said, Egypt with special references to its pathological alterations. Researcher. 5(2): 5-14.

Haq, A.; Abdullatif, M.; Lobo, P.; Khabar, K.; Sheth, K. and Alsedairy, S. (1995): Nigella sativa effect on human lymphocytes and polymorphonuclear leucocytes phagocytic activity. Immunopharmacol., 30 (2): 147-155. 
Kitao, T.; Aoki, T.; Fukudome, M.; Kawano, K.; Wada, Yo. and Mizuno, Y. (1993): Serotyping of Vibrio anguillarum isolated from fresh water fish in Japan. Journal of fish diseases. 6: 175-181.

Khalil, S.A.; Khalil, R.H.; Saad, T.T. and Safaa, M.H. (2010): Studies on pseudomonas septicemia among cultured Oreochromus niloticus. Journal of the Arabian aquaculture society. 5 (1): 55-64.

Logambal, SM. and Michael, RD. (2000): Immunostimulatory effect of Azadirachtin in Oreochromis mossambicus (Peters). Indian J. Exp Biol 38: 1092-1096.

Mahdi, H. (1993): Effect of Nigella sativa L. on the immune system in cirrhotic patients. MDSc, Fac. Med., El-Azhar University, Egypt.

Mona, Z.; Rakha, G.; Osfor, M.; Bayumi, F. and Saad, M. (2002): Some clinicopathological and microbiological changes with hypercholestrimia in sheep and a trial of treatment with Nigella sativa and Titanium ascorbate. Bull. NRC., Egypt.

Mortia, R.T. (1975): Psychrophilic bacteria. Bact. Rev. 39: 144-167.

Nerberto, J. Palleroni. (1984): Family pseudomonadaceae in in Bergey's manual of systemic bacteriology. Vol. 1 (Ed. By Krieg, R.N. and Holt, J.G.) pp. 141-199. Williams and Wilkins Company, Baltimore Md., U.S.A.
Plumb, J.A. and Bowser, P.R. (1982): Laboratory manual of microbial fish diseases. Aubrun univ., Auburn, Alabama, 70-77.

Roberts, R.J. (2001): Fish pathology, $3^{\text {rd }}$ edn. W. B. saunders, Philadelphia, PA.

Sakar, S.F.M. and Azza, M.M.A. (2008): Contribution on Pseudomona septicemia caused by $P S$. anguilliseptica in cultured Oreochromis niloticus. fish Diseases Dept., Central lab for Aquaculture Research,Abbassa, Agriculture Research Center, Egypt, 1177-1197.

Saleh, F.; Sakr, M.; Azza, M. and Abd El-Rahman, M. (2008): Contribution on pseudomonas septicemia caused by Pseudomonas anguilliseptica in cultured Oreochromis niloticus. 8 International Symposium on Tilapia in Aquaculture. Cairo International Convention Center, Egypt12-14/10. 2: 1177-1197.

Whyte, SK. (2007): The innate immune response of finfish--a review of current knowledge. Fish Shellfish Immunol 23: 1127-1151.

Yilmaz, S.; Ergiin, E. and Tiirk, N. (2012): Effects of Cumin-Supplemented Diets on Growth and Disease (Streptococcus iniae) Resistance of Tilapia (Oreochromis mossambicus). The Israeli Journal of Aquaculture .64: 768 -773.

Zilberg, D.; Tal, A.; Froyman, N.; Abutbul, S.; Dudai, N. and Goldhirsh, A.G. (2010): Dried leaves of Rosmarinus officinalis as a treatment for Streptococcosis in tilapia. J. Fish Dis., 33: 361-369.

\title{
دور الحبة السوداء فى تقليل الوفيات فى السيدوموناس الدموية فى اسماك البلطى النيلى
}

\author{
آبية جلال سعد الدين \\ Email: aya9galal@gmail.com
}

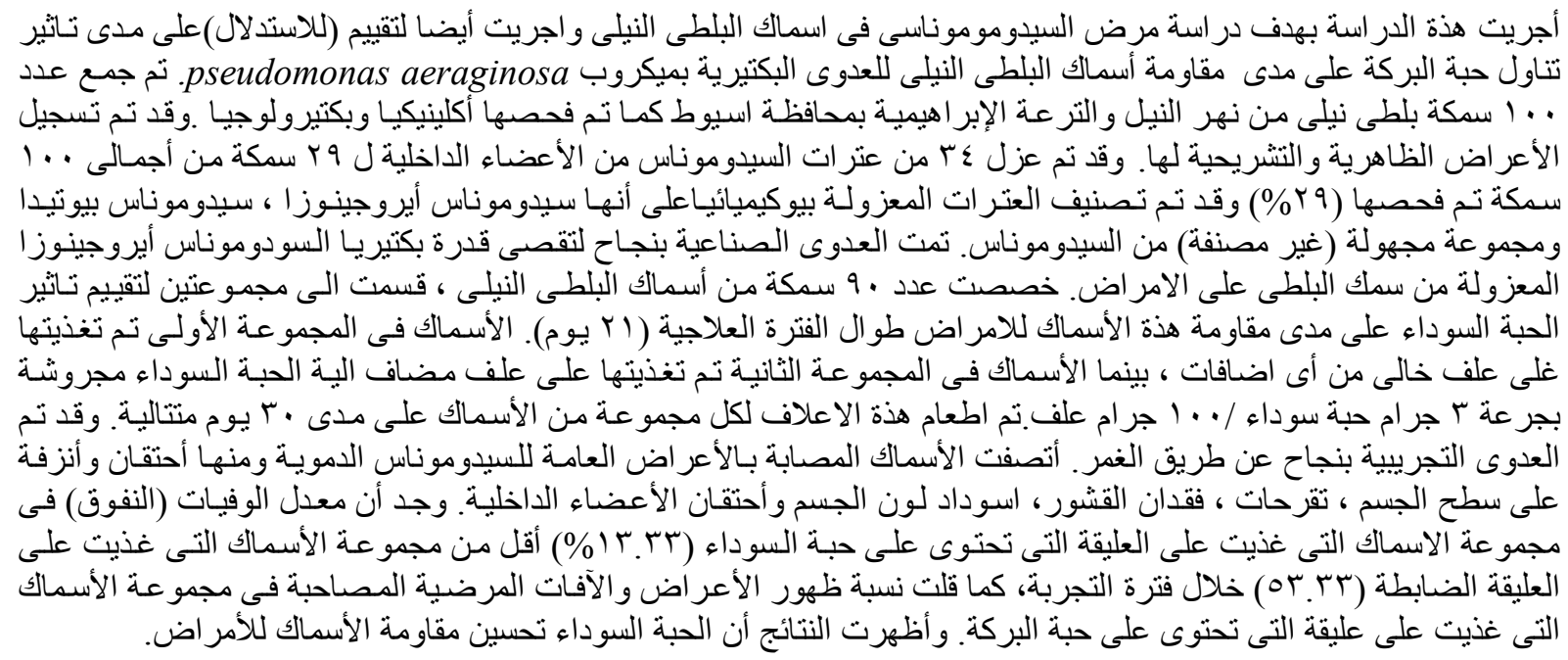

